\title{
A Purpose for Further European Unity?
}

Steve Lee*

Unifying Europe is an ambition that must have a purpose. It is no longer clear what that purpose is. Unless there is clarity shared among broad populations who then grant legitimacy to their elected governments and leaders to advance European unity (with the knowledge that there are increasingly perceived risks and costs to that), unity will not advance, and existing hard won unity may falter as we see already with, among others, the on-going Greek crisis, serious concerns about the viability of the euro, Brexit, high level questioning of Turkey as an EU candidate and Visegrad views and policies. As is well recognized now by national leaders across the European Union and beyond, top down driven unity efforts in the absence of overwhelming public and voter support, whatever the core/outer group or speeds, will not succeed and can fuel further alienation from and opposition to the "European Project."

Past efforts up to and including the post-World War steps leading to the current European Union have always had a driving purpose, for good or ill. Unity through domination of the continent by one group, over all others, to secure peace and thus the possibility (especially for the dominant group) of greater prosperity, including dominion over human souls, was more often than not the driver. Drawing on the lessons of preceding crisis moments through the 18th, 19th and early 20th Centuries, the formation of (West) European cooperation, structures and practices of unity were specifically designed to prevent Germany and France from going to war, and thus to prevent further European wide wars that, as well, at least twice had already been global in impact. Underlying that goal was the perpetual fear of domination of the whole of Europe by one or other great power. No credible case can be made today that preventing France and Germany from going to war is the driving purpose of European unity or "more Europe" in the roll out of a potentially reformed European Union. Can we test the current purposes? Can there be a purpose to European unity going forward? And, if so, what could it, what should it be?

The European Union as an inter-government arrangement with a set of supra-national administrative institutions has specific purposes. Our task 
is wider than an examination of those. The purpose of further unifying Europe, from a citizen perspective, must be clear in order to ensure that institutions and rules put in place (a reformed European Union, other) are democratically valid, legitimate and sustainable. It can be helpful to differentiate further European unity, on the one hand, and growth in inter-government cooperation (such as regulation harmonization in a free trade area/common market), on the other. For example, the Canada - United States bi-lateral trade partnership is the world's largest, with a vast range of enabling mechanisms, and no objective of North American unity. (1) These days "America First", in fact, is quite the opposite. Inter-government cooperation to achieve specific goals (like common standards for medicine, or joint perimeter military surveillance), and advancing unity for a larger purpose, are different. The added value of (greater) unification should outweigh the apparent and likely future costs (such as loss of national sovereignty and identity, loss of budgetary and currency control, slow/ineffective policy and decision making, democratic "distance", and other). Citizens should remain convinced that the costs beyond inter-government cooperation are desirable (or at least bearable) in order to achieve a greater purpose. For Europe today and going forward, what is that purpose?

\section{Preventing a European War}

Further European unity to prevent war between France and Germany and/or to prevent a wider European/world war appears to have no basis in current realities. From a citizen point of view, the possibility of such a war does not even register on the EU public radar of threats. And, all of the threats mentioned by citizens can be further addressed functionally by enlarged inter-government cooperation, which essentially must include States outside Europe. "More Europe" is not an obvious part of the threat responses.

Roughly half of the respondents (49\%) identified terrorism as one of the EU's most important security challenges. This is a substantial increase from the 33\% of respondents who mentioned terrorism in 2011 (Special Eurobarometer 371). Over a quarter of respondents (27\%) think that economic and financial crises are among the most important challenge to security, down from $34 \%$ in 2011 . (2) 
There is also no apparent need for "more Europe" geographically for European countries outside the European Union - the possibility of war with Norway or Switzerland is out of consideration and there is no need to include them in further European unity for the purpose of preventing war. Geographically enlarging European unity to include former Soviet States in the European Union is as much likely to be the cause of future conflict than preventative (there are plenty of sober lessons to be learned from the Ukraine experience). The only case for expanding European unity geographically that might arguably help prevent future (local) conflicts would be to finish the inclusion in the European Union of the former Yugoslavian/Balkan States and finalize Turkey's speedy path to EU membership. However, nearly all of these States, including Turkey, belong to NATO already (the others are candidates) and share NATO membership with nearly all EU States (along with Canada and the United States) thus ensuring a zero possibility of NATO area inter-State military conflict whether they are in our outside the EU.

\section{Promoting EU Values}

Advancing further European unity with the purpose of promoting shared values is equally problematic. According to EU documents, "the European Union's fundamental values are respect for human dignity and human rights, freedom, democracy, equality and the rule of law. These values unite all the member states - no country that does not recognise these values can belong to the Union. The main goal of the European Union is to defend these values in Europe and promote peace and the wellbeing of the citizens. The EU member states are pluralistic. Nobody may be discriminated against; instead, people and government representatives must respect others and be tolerant. Everybody must be treated fairly. Minority rights must be respected. Equality between men and women is promoted. Responsibility must be shared." (2)

There are several important and somewhat hidden factors to take note. Underlying these EU articulated values are other values: humanistic, rational, secular. To set the EU goals and the purpose of further unification as the defence of "human rights, freedom, democracy, equality, and the rule of law" societies (people) will first (likely mostly subconsciously) value a human-centered world, and a world view that is largely rational and secular (that may have a personal space for God and religion but not a space 
for European unity to be based on those). The values are also modern in that they are expressly about human rights including equality. Reflecting this modernity, the EU values are about the person and her relationship to others and to the State.

This is not to diminish the central importance of human rights in modern human affairs, but rather to note the importance of words in treaties and documents that commit and instruct State parties such as members States of the EU. What happens if, at some moment in time for whatever reason, a member State (government) can't, say, respect minority rights like marriage equality for sexual minorities? Or can't, for whatever reason, share responsibility for, say, unplanned, large migrations of refugees and their need for re-settlement? The foundational directives that they must do so or face not belonging to the Union invites inevitable crises. This is a fragile foundation upon which to build further European unity.

Furthermore, the ongoing work by the World Values Survey (WVS) (3) provides a map of the diverse and potentially conflicting values held across the $28 \mathrm{EU}$ members States and their societies. In summary, analysis of WVS data made by political scientists Ronald Inglehart and Christian Welzel portrays two major dimensions of values in the world:

Traditional values versus Secular-rational values and Survival values versus Self-expression values.

As described by the WVS team, traditional values emphasize the importance of religion, parent-child ties, deference to authority and traditional family values. People who embrace these values also reject divorce, abortion, same sex relations, euthanasia and suicide. These societies have high levels of national (collective) pride and a nationalistic outlook. Secular-rational values have the opposite preferences to the traditional values. These societies place less emphasis on religion, traditional family values and authority. Divorce, abortion, same sex relations, euthanasia and suicide are seen as relatively acceptable.

Survival values place emphasis on economic and physical security. This is linked with a relatively ethnocentric outlook and low levels of trust and tolerance. Self-expression values give high priority to environmental protection, growing tolerance of foreigners, gays and lesbians and gender equality, and rising demands for (individual) participation in decisionmaking in economic and political life.

For our discussion, several things stand out from these findings. African societies (and the African Union and its members States) can realistically 
claim to hold a common set of values. Those values are overwhelmingly traditional (the importance of religion, family ties, group/tribe/national pride and outlook, etc. with South Africa being slightly more secular than others), and not surprisingly heavily skewed to survival values, with Tanzania and Ghana (among the more secure practicing democracies on the continent) valuing self-expression on a par with Brazil and South Korea. Latin America, too, shares a fairly common set of values, with Chile and Argentina a bit less traditional values-based than others. The English speaking settler countries, USA, Canada, New Zealand and Australia share common values, though it is noteworthy that the USA is most traditional values-based country among almost all highly developed economies (something skilfully exploited by the Donald Trump campaign in 2016).

The most striking feature, however, is that there is simply no common set of European values as measured and mapped over a long time by the WVS (this is revealed in Eurobarometer public opinion surveys, as well). The diversity is extreme. The potential for conflicts over values being the most acute in the global landscape. EU member States and societies, Sweden and Romania, could not be further apart in values. Ireland is more traditional than Turkey, Estonia more rational-secular than China. As measured here, the people of Denmark highly value self-expression, the people of Hungary do not. Poland and India are twins in their attachment to traditional and survival values.

While elites across Europe may hold a common set of values (as has been the case through history), to claim that EU populations have a common, deep rooted affection for a fundamental set of non-traditional, selfexpression "modern" values is inaccurate at best. As presented by the WVS, such a claim is a measurable fantasy. To continue to define the purpose of the EU and especially to set the purpose of further unity as the defence of these values is likely to doom the EU to increasing alienation from many, at best, and likely to contribute to mounting crises and policy/ political conflicts. It will be a long time before the societal values of either Romania or Sweden change to meet or even meet the current Greek "median" position of EU member values.

"We signed up for European values of liberal democracy, rule of law, transparency and the upholding of human rights, but we did not internalize them," Mr. Milo said. "They are still seen as something foreign or alien to our national character." (4) 


\section{Trade, economic growth, human development}

So, if no longer needed to prevent war, and if not well founded on common values, is there a purpose to further European unity? Economic growth, shared prosperity and improved social welfare appear to be the most fertile ground as a purpose.

The most recent Eurobarometer of public opinion ${ }^{(5)}$ suggests there could be modest public support to build on this as a purpose for further European unity (especially among people in New Member States). It is not a surprise that populations in the less affluent parts of Europe would look to "outside" (i.e. EU institutional) assistance for economic growth and shared prosperity to a larger extent than polling shows in the first $15 \mathrm{mem}$ ber States. In addition, there is some public interest in EU support to improve the standard of living. This is an urgent need, more generally, as current research shows (6) inequality is already growing in Europe and real wages for much of the continent are predicted to stagnate or fall through 2018. Rising inequality and stalled or falling living standards will have increasing illiberal political effects (exactly opposite to the values goals of the EU).

One purpose for further European unity, then, can be to ensure that Europe's trade success (both EU internal trade and external global trade) contributes to shared growth that improves standards of living, social welfare and human development much more than is the case today.

The increasing discontent with trade and globalisation may have to do with the inadequate manner in which welfare states are performing their redistributive and insurance roles. Economists should not be puzzled by the discontent with which trade and globalisation is being met. Trade's undesirable side-effects have been known to economists for almost as long as the positive net gains. It is important to develop effective tools to keep the negative side-effects in check so as to ensure acceptance of the welfare-enhancing liberal world order. If the benefits of trade are too unevenly spread, it will prove impossible to sustain the system that generates them. (7)

In addition, cast today as the villain of globalization by populist politicians and other critics, further European unity could improve its own reputation by championing tools and support measures to help strengthen the ability of member States to fulfil their "welfare state" responsibilities and thus address the negative impacts of trade and globalization. 
Here, the global experience of the United Nations Development Programme offers some helpful suggestions about sharing the benefits of trade to improve social welfare (or what the UN describes as Human Development), totally applicable to Europe today even though written in the context of developing country needs (and keeping in mind all member States of the EU, as member States of the United Nations, have agreed to achieve the UN 17 Sustainable Development Goals by 2030). ${ }^{(8)}$

Trade's contribution to development continues to be seen primarily in the context of economic growth, on the premise that trade expansion will engender economic growth, which in turn will provide developmental benefits for all. However, trade on its own cannot deliver development objectives; rather, a host of complementary policies and actions are required along with the right sequencing. Hence the need to sensitize stakeholders to the complex relationship among trade, growth and human development and the need to strategically use trade along with other policies to achieve development objectives....Achieving this requires leadership, political will, effective institutional frameworks, strong analytical skills, planning and management capacities and coordination. ${ }^{(9)}$

To set this as the purpose of further European unity, something well beyond inter-government cooperation, would require wide popular support and the support of European national governments. By nature, governments and competing national political parties do not like their policy space and prescriptions curtailed. And the days of building European unity through the back door (the constitution, the Commission, non-transparency, etc.) must be truly over if European unity is to survive. Significant debate, discussion and agreement would be required. Powerful interests and stakeholders in the current trade-growth circumstances would have to be accommodated. Interests, movements, political parties not strongly attached to re-distribution, addressing inequality and enlarged social welfare would have to agree, or remain passive, to the future purpose of European unity along these lines. On the other hand, many are already seized with the needs that national governments alone seem unable to meet. Among them, as an opening to possible political support for this purpose for European unity, recently European and other social democrat parties resolved "...To ensure growth means social growth and greater equality." (10)

Could there be a better purpose for further European unity?

*Steve Lee served the United Nations as senior advisor in Tanzania for the past seven years and with the UN in Afghanistan and the OSCE in Bosnia. 
He taught at Law Faculty Comenius University Bratislava where he helped establish the Institute for International Relations. He was awarded the Presidential medal of Slovakia and the University medal for contributions to education and democracy. He is a CIFE graduate of the North American European Summer Academy and taught at that summer school for 20 years. He is an internationally recognised parliament expert recently assisting the Parliament of Fiji.

\section{Further information and sources}

1. North American Free Trade Agreement www.naftanow.org In 1994, the North American Free Trade Agreement (NAFTA), a state-of-the-art market-opening agreement, came into force. Since then, NAFTA has systematically eliminated most tariff and non-tariff barriers to trade and investment between Canada, the United States, and Mexico. By establishing a strong and reliable framework for investment, NAFTA has also helped create the environment of confidence and stability required for long-term investment. NAFTA was preceded by the Canada-U.S. Free Trade Agreement. A number of NAFTA institutions work to ensure smooth implementation and dayto-day oversight of the Agreement's provisions.

\section{Free Trade Commission}

Made up of ministerial representatives from the NAFTA partners.

\section{NAFTA Coordinators}

Senior trade department officials designated by each country.

\section{NAFTA Working Groups and Committees}

Over 30 working groups and committees have been established to facilitate trade and investment and to ensure the effective implementation and administration of NAFTA Key areas of work include trade in goods, rules of origin, customs, agricultural trade and subsidies, standards, government procurement, investment and services, cross-border movement of business people, and alternative dispute resolution.

\section{NAFTA Secretariat}

Made up of a "national section" from each member country.

\section{Commission for Labor Cooperation}

Created to promote cooperation on labor matters among NAFTA members and the effective enforcement of domestic labor law. Consists of a Council of Ministers (comprising the labor ministers from each country) and a Secretariat, 


\section{Commission for Environmental Cooperation}

Established to further cooperation among NAFTA partners in implementing the environmental side accord to NAFTA and to address environmental issues of continental concern. Consists of a Council (comprising the environment ministers from each country), a Joint Public Advisory Committee and a Secretariat www.cec.org/council.

2. Special Eurobarometer 432: Europeans' Attitudes Toward Security. Eurobarometer. EC. April 2015

3. World Values Survey. The WVS has over the years demonstrated that people's beliefs play a key role in economic development, the emergence and flourishing of democratic institutions, the rise of gender equality, and the extent to which societies have effective government. www.worldvaluessurvey.org go to maps. The one below is 2015 .

4. Not Even a Prosperous Slovakia is Immune to Doubts About the EU. New York Times. Steven Erlanger. 17 December 2016

Slovakia and the Czech Republic are "moving in the same direction as Poland and Hungary," he said. Russia, Mr. Milo added, "is very good at playing on these sentiments in this whole region." For those "disquieted by this liberal world," Mr. Beblavy said, "Russia is seen as the only bulwark of traditional values."

5. Special Eurobarometer 451: The Future of Europe. Eurobarometer EC. December 2016.

The country analysis reveals important variations between EU15 and NMS13 countries. In EU15 countries, respondents are much more likely to mention the EU's respect for democracy, human rights and the rule of law ( $35 \%$ vs. $25 \%$ in NMS13 countries). This is the most mentioned asset in EU15 countries, while in NMS13 countries it ranks fourth. In NMS13 countries, on the other hand, the standard of living of EU citizens is the most mentioned asset (34\% vs. 18\%) - in EU15 countries this asset ranks fourth. Respondents in NMS13 countries are also more likely than those in EU15 countries to say the quality of infrastructure in the EU is one of its main assets (17\% vs. $10 \%)$. His asset ranks fifth amongst respondents in NMS13 countries, but eighth in EU15 countries.

6. Income inequalities and employment patterns in Europe before and after the Great Recession. Enrique Fernandez-Macias, Carlos Vacas-Soriano. Eurofound. 13 March 2017

The results show that EU-wide income inequality declined notably prior to 2008, driven by a strong process of income convergence be- 
tween European countries - but the Great Recession broke this trend and pushed inequalities upwards both for the EU as a whole and across most countries. While previous studies have pointed to widening wage differentials as the main driver behind the long-term trend towards growing household disposable income inequalities across many European countries, this report identifies unemployment and its associated decline in labour income as the main reason behind the inequality surges occurring in recent years. Real income levels have declined and the middle classes have been squeezed from the onset of the crisis across most European countries.

7. Globalisation and the Welfare State: Can the Welfare State Still Keep Up with Globalisation? Dr.Christian Bluth. Bertelsmann Stiftung. May 2017 www.ged-project.de

8. On 1 January 2016, the 17 Sustainable Development Goals (SDGs) of the 2030 Agenda for Sustainable Development - adopted by world leaders in September 2015 at an historic UN Summit - officially came into force. Over the next fifteen years, with these new Goals that universally apply to all, countries will mobilize efforts to end all forms of poverty, fight inequalities and tackle climate change. www.un.org/s ustainabledevelopment/sustainable-development-goals/

9. Trade and Human Development: A Practical Guide to Mainstreaming Trade. United Nations Development Programme. Trade and Human Development Unit. Geneva. July 2011. www.undp.org/poverty

10. For a World in Peace, Equality and Solidarity. Socialist International Congress, Cartagena, Colombia, 02-04 March 2017. www.socialistint ernational.org 